\title{
Analisis Kemampuan Regulasi Diri Dan Motivasi Belajar Mahasiswa Pada Masa Pembelajaran Daring
}

\author{
Ruli Meiliawati $^{(1)}$, Anggi Ristiyana Puspita Sari ${ }^{(1)}$ \\ ${ }^{1}$ Pendidikan Kimia, Fakultas Keguruan dan Ilmu Pendidikan, Universitas \\ Palangka Raya, Indonesia \\ Email: anggi.ristiyana@fkip.upr.ac.id
}

Diterima: 21-10-2021; Diperbaiki:24-10-2021; Disetujui:25-10-2021

\begin{abstract}
ABSTRAK
Di era pandemi ini seluruh universitas harus menerapkan pembelajaran daring yang tentunya dapat mempengaruhi kondisi interpersonal mahasiswa. Perubahan keadaan ini juga dapat mempengaruhi kualitas kinerjanya. Penelitian ini merupakan penelitian kuantitaif deskriptif yang bertujuan untuk mengetahui: 1) perbedaan kemampuan regulasi diri pada mahasiswa cumlaude dan non-cumlaude, 2) perbedaan motivasi belajar pada mahasiswa cumlaude dan non-cumlaude, 3) korelasi regulasi diri, motivasi belajar, dan prestasi pada mahasiswa cumlaude, dan 4) korelasi regulasi diri, motivasi belajar, dan prestasi pada mahasiswa noncumlaude. Teknik pengumpulan data menggunakan teknik angket dengan instrumen berupa kuesioner regulasi diri dan motivasi belajar yang keduanya merupakan kuseioner hasil adaptasi. Data yang diperoleh kemudian dianalisis menggunakan uji $\mathrm{t}$ sampel bebas dan uji korelasi menggunakan program SPSS. Hasil penelitian yang diperoleh menunjukkan bahwa: 1) terdapat perbedaan kemampuan regulasi diri pada mahasiswa cumlaude dan non-cumlaude, 2) terdapat perbedaan motivasi belajar pada mahasiswa cumlaude dan noncumlaude, 3) terdapat korelasi regulasi diri, motivasi belajar, dan prestasi pada mahasiswa cumlaude, dan 4) tidak terdapat korelasi regulasi diri, motivasi belajar, dan prestasi pada mahasiswa non-cumlaude.
\end{abstract}

Kata kunci: korelasi, motivasi, pembelajaran daring, prestasi, regulasi diri

\section{PENDAHULUAN}

Kemajuan zaman yang selalu mengandalkan teknologi didalam setiap aspek sebenarnya sudah diprediksi dari sejak lama oleh para ahli (Corbeil \& Corbeil, 2015). Seluruh sektor seperti manufaktur, ekonomi, kesehatan dan tidak terkecuali pendidikan perlahan mulai mempersiapkan diri untuk menghadapi tantangan era industri 4.0. Kualitas sumber daya manusia (SDM) perlu ditingkatkan agar kedepannya bisa menghadapi tantangan yang semakin kompleks dan tidak dapat diprediksi. Oleh karena itu, pendidikan memegang peran penting dalam membentuk SDM yang berdaya saing unggul.

Pendidikan juga mengalami revolusi sebagai bentuk respon terhadap setiap tahap perkembangan revolusi industri. Perubahan ini bertujuan untuk dapat memenuhi kebutuhan industri di masa mendatang dengan meningkatkan keterampilan mahasiswa agar memiliki kecakapan dalam bekerja ditengah ketatnya persaingan global (Saxena et al., 2017). Pembelajaran konvensional sudah tidak lagi relevan dengan era pendidikan 4.0. Kecanggihan teknologi perlahan sudah mulai 
diterapkan dalam setiap kegiatan pembelajaran di beberapa instansi yang memiliki fasilitas memadahi. Namun, semenjak pandemi COVID-19 seluruh instansi dipaksa untuk menggunakan teknologi. Hal ini menimbulkan problematika bagi instansi yang tidak memiliki fasilitas yang cukup memadahi untuk melakukan pembelajaran jarak jauh (distance learning).

Pembelajaran jarak jauh melalui sistem pembelajaran daring (online learning) menimbulkan berbagai problematika. Beberapa masalah yang muncul diantaranya ketidaksiapan instansi terhadap pembelajaran daring, perubahan sistem belajar yang mendadak, mahasiswa dari kalangan menengah ke bawah yang tidak memiliki anggaran dalam menyediakan device dan jaringan internet, serta masih banyak lagi (Asmuni, 2020; Diningrat et al., 2020). Seluruh komponen yakni instansi, pendidik, mahasiswa, dan orang tua harus mampu bekerja sama untuk bisa menghadapi tantangan ini. Dosen dan mahasiswa merupakan kunci utama yang harus mulai berbenah diri karena memiliki peran penting yang secara langsung terlibat dalam proses pembelajaran. Sementara itu, perguruan tinggi hendaknya menyediakan fasilitas yang memadahi untuk mendukung kegiatan pembelajaran.

Selama pembelajaran daring intensitas pertemuan antara dosen dan mahasiswa menjadi berkurang. Hal ini sesungguhnya tidak menjadi masalah yang besar bagi mahasiswa karena sejatinya mahasiswa memang dituntut untuk mandiri. Namun, berdasarkan hasil observasi selama kegiatan perkuliahan semester genap tahun ajaran 2020/2021 masih banyak mahasiswa yang memiliki kemandirian belajar yang rendah. Mahasiswa enggan mencari pengetahuan dari sumber lain dan hanya mengandalkan penjelasan dari dosen, selain itu mahasiswa juga memiliki umpan balik yang rendah dengan jarang menanggapi penjelasan dari dosen. Kondisi tersebut mengindikasikan bahwa selain faktor eksternal yang harus diperbaiki, faktor internal dari dalam diri mahasiswa juga perlu ditingkatkan untuk bisa mencapai keberhasilan dalam pembelajaran daring.

Kemampuan regulasi diri merupakan salah satu faktor yang mempengaruhi kemampuan belajar mahasiswa karena kemampuan inilah yang mengatur perilaku belajar mahasiswa (Wong et al., 2019). Baldan Babayigit (2020) menyatakan bahwa kemampuan ciri-ciri mahasiswa yang memiliki kemampuan regulasi yang tinggi adalah strategik, proaktif, mampu mengontrol perilaku belajar dan yang terpenting adalah mampu menyelesaikan masalah selama proses pembelajaran. Wandler \& Imbriale (2017) juga menambahkan bahwa mahasiswa dengan level regulasi diri yang baik akan mampu mengintegrasikan proses pembelajaran dengan strategi pembelajaran yang tepat. Contoh strategi tersebut diantaranya mengatur jadwal belajar, aktif mencari jalan keluar dari permasalahan pembelajaran yang dihadapi, menyimpan dan menyusun materi pembelajaran dengan rapi.

Faktor internal lain yang mempengaruhi proses pembelajaran yaitu motivasi belajar. Penelitian Muslimin dan Harintama (2020) mengungkap bahwa pembelajaran daring merupakan suatu kondisi yang dapat mempengaruhi motivasi belajar karena tantangan yang diberikan dapat memancing keinginan mahasiswa 
untuk menyelesaikan masalah. Beberapa penelitian (Harandi, 2015; Sharif et al., 2014; Widjaja \& Chen, 2017) menyatakan bahwa selama pembelajaran daring motivasi belajar menjadi meningkat dibandingkan pada saat pembelajaran tatap muka dilihat dari segi teknologi yang digunakan. Media pembelajaran yang digunakan oleh mahasiswa saat ini menggunakan device yang dalam kegiatan sehari-hari tidak bisa lepas dari mahasiswa. Namun, apabila dilihat dari segi strategi dan metode pembelajaran, motivasi belajar cenderung menurun apabila dibandingkan dengan pertemuan tatap muka di kelas. Oleh karena itu, penelitian ini bertujuan untuk menganalisis perbedaan kemampuan regulasi diri dan motivasi belajar pada mahasiswa cumlaude dan non-cumlade serta menganalisis pengaruh atau korelasi antara kemampuan regulasi diri, motivasi belajara, dan prestasi belajar pada mahasiswa cumlaude dan non-cumlaude.

\section{METODOLOGI PENELITIAN}

Penelitian ini merupakan penelitian kuantitatif deskriptif karena didalam penelitian ini tidak ada perlakuan pada variabel-variabel penelitian. Variabel bebas pada penelitian ini adalah kemampuan regulasi diri dan motivasi belajar mahasiswa, sedangkan variabel terikat pada penelitian ini adalah prestasi belajar mahasiswa yang berupa indeks kumulatif (IP) pada semester genap tahun ajaran 2020/2021.

Populasi pada penelitian ini adalah mahasiswa FKIP Universitas Palangka Raya yang berjumlah 5876 orang. Penarikan sampel didasarkan pada tabel Krejcie dan Morgan (1970) yakni dari jumlah populasi sebanyak 5876 mahasiswa maka sampel yang digunakan sebanyak 361 mahasiswa. Teknik sampling yang digunakan adalah stratified cluster random sampling yaitu pemilihan sampel yang diambil dari setiap angkatan mulai dari angkatan 2017 - 2020 kemudian diambil secara acak dari berbagai program studi. Teknik sampling tersebut digunakan karena penelitian ini bertujuan untuk menguji adanya perbedaan dan pengaruh antara dua kelompok sampel yang berbeda yaitu mahasiwa cumlaude dan noncumlaude. Berdasarkan jumlah sampel tersebut diperoleh 206 mahasiswa cumlaude dan 155 mahasiswa non-cumlaude.

Instrumen yang digunakan pada penelitian ini berupa angket kuesioner untuk mengukur kemampuan regulasi diri dan motivasi belajar mahasiswa. Kuesioner motivasi belajar yang digunakan adalah Motivated Strategies for Learning Questionnaire (MLSQ) diadaptasi dari Pintrich \& DeGroot (1990). Kuesioner tersebut memiliki 56 butir pernyataan dengan reliabilitas pada masingmasing aspek yakni efikasi diri $(\alpha=0.89)$, faktor instrinsik $(\alpha=0,87)$, kecemasan $(\alpha=0,75)$. Sementara itu, kuesioner regulasi diri (self-regulated learning, SRL) diadaptasi dari Gaumer Erickson \& Noonan (2017) yang memiliki 22 butir pernyataan dan terbukti reliabel $(\alpha=0,894)$. Kedua kuesioner tersebut merupakan angket skala Likert.

Analisis data yang digunakan dalam penelitian ini adalah uji t sampel bebas (independent sample t-test) dan uji korelasi. Uji t sampel bebas digunakan untuk 
mengetahui ada tidaknya perbedaan kemampuan regulasi diri dan motivasi belajar pada mahasiswa cumlaude dan noncumlaude, sedangkan uji korelasi digunakan untuk mengetahui pengaruh kemampuan regulasi diri dan motivasi belajar terhadap prestasi pada mahasiswa cumlaude dan noncumlaude. Oleh karena itu, terdapat empat hipotesis yang diajukan dalam penelitian ini yakni sebagai berikut.

1. Ho: tidak ada perbedaan kemampuan regulasi diri yang signifikan pada mahasiswa

cumlaude dan non-cumlaude.

Ha: ada perbedaan kemampuan regulasi diri yang signifikan pada mahasiswa cumlaude

dan

non-cumlaude.

2. Ho: tidak ada perbedaan motivasi belajar yang signifikan pada mahasiswa cumlaude

dan non-cumlaude.

Ha: ada perbedaan kemampuan regulasi diri yang signifikan pada mahasiswa cumlaude

dan non-cumlaude.

3. Ho: tidak ada pengaruh kemampuan regulasi diri dan motivasi belajar yang signifikan

terhadap prestasi belajar pada mahasiswa cumlaude.

Ha: tidak ada pengaruh kemampuan regulasi diri dan motivasi belajar yang signifikan

terhadap prestasi belajar pada mahasiswa cumlaude.

4. Ho: tidak ada pengaruh kemampuan regulasi diri dan motivasi belajar yang signifikan

terhadap prestasi belajar pada mahasiswa non-cumlaude.

Ha: tidak ada pengaruh kemampuan regulasi diri dan motivasi belajar yang signifikan

terhadap prestasi belajar pada mahasiswa non-cumlaude.

\section{HASIL PENELITIAN DAN PEMBAHASAN}

\section{Analisis Perbedaan Kemampuan Regulasi Diri dan Motivasi Belajar pada} Mahasiswa Cumlaude dan Non-cumlaude

Uji t sampel bebas digunakan untuk menguji hipotesis 1 dan 2 yaitu mengetahui ada tidaknya perbedaan regulasi diri dan motivasi belajar mahasiswa pada masa pembelajaran daring. Sebelum dilakukan analisis data, terlebih dahulu dilakukan uji persyaratan hipotesis yang terdiri atas uji normalitas dan uji homogenitas sampel (Cohen et al., 2018). Uji normalitas dibuktikan dengan uji Kolmogorov-Smirnov, sedangkan uji homogenitas dibuktikan dengan uji Lavene's menggunakan program SPSS 20. Hasil uji normalitas menunjukkan bahwa baik data regulasi diri maupun motivasi belajar dinyatakan berdistribusi normal karena diperoleh nilai sig > 0,05. Hasil uji normalitas dapat dilihat pada Tabel 1. 
Tabel 1. Hasil Uji Normalitas

\begin{tabular}{|c|c|c|c|c|}
\hline \multirow{2}{*}{\multicolumn{2}{|c|}{ Kelompok }} & \multicolumn{3}{|c|}{ Kolmogorov-Smirnov ${ }^{\mathrm{a}}$} \\
\hline & & \multirow{2}{*}{$\begin{array}{c}\text { Statistic } \\
.119\end{array}$} & \multirow{2}{*}{$\frac{\mathrm{df}}{204}$} & \multirow{2}{*}{$\frac{\text { Sig. }}{.200}$} \\
\hline Regulasi diri & Cumlaude & & & \\
\hline & Noncumlaude & .140 & 153 & .200 \\
\hline \multirow[t]{2}{*}{ Motivasi belajar } & Cumlaude & .093 & 204 & .200 \\
\hline & Noncumlaude & .131 & 153 & .200 \\
\hline
\end{tabular}

Sementara itu, uji homogenitas juga diperoleh nilai sig $>0,05$. Hasil ini menunjukkan bahwa kedua data tersebut berasal dari populasi yang homogen. Hasil uji homogenitas dapat dilihat pada Tabel 2. Oleh karena itu, uji asumsi ini terpenuhi dan dapat dilanjutkan analisis data menggunakan uji t sampel bebas.

Tabel 2. Hasil Uji Homogenitas

\begin{tabular}{lcc}
\hline \multirow{2}{*}{ Kelompok } & \multicolumn{2}{c}{ Equality of Variances } \\
\cline { 2 - 3 } & $\mathrm{F}$ & Sig. \\
\hline Regulasi diri & .064 & .801 \\
\hline Motivasi belajar & 1.010 & .315 \\
\hline
\end{tabular}

Hasil uji t sampel bebas yang ditunjukkan pada Tabel 3 menunjukkan bahwa Ho ditolak karena nilai sig $<0.05$ (Cohen et al., 2018). Hasil tersebut membuktikan bahwa hipotesis 1 dan 2 terbukti. Dengan kata lain, terdapat perbedaan kemampuan regulasi diri pada mahasiswa cumlaude dan non-cumlaude dan terdapat perbedaan motivasi belajar pada mahasiswa cumlaude dan non-cumlaude.

Tabel 3. Hasil uji t sampel bebas

\begin{tabular}{lccc}
\hline \multirow{2}{*}{ Kelompok } & \multicolumn{3}{c}{ t-test for Equality of Means } \\
\cline { 2 - 4 } & $\mathrm{t}$ & $\mathrm{df}$ & Sig. (2-tailed) \\
\hline Regulasi diri & 44.170 & 359 & .000 \\
\hline Motivasi belajar & 69.098 & 359 & .000 \\
\hline
\end{tabular}

Adanya perbedaan tersebut disebabkan dengan adanya transformasi kondisi dan situasi pembelajaran. Mahasiswa yang memiliki kemampuan regulasi diri dan motivasi belajar yang tinggi justru menjadi tertantang dan semakin mempersiapkan diri dengan adanya transformasi tersebut, sehingga pembelajaran daring ini menjadikannya lebih termotivasi untuk meningkatkan prestasi belajarnya (Dron, 2018). Sebaliknya, rendahnya kemampuan regulasi diri dan motivasi belajar mahasiswa dapat mengakibatkan ketertinggalan proses belajar selama pembelajaran daring karena pada masa pembelajaran daring mahasiswa dituntut untuk lebih aktif, mandiri, dan pintar mengatur dirinya sendiri. Apabila mahasiswa 
tidak mampu mengejar ketertinggalan tersebut, maka akan berdampak buruk bagi prestasi belajarnya (Baldan Babayigit \& Guven, 2020; Wong et al., 2019).

\section{Analisis Korelasi Kemampuan Regulasi Diri, Motivasi Belajar, dan Prestasi Belajar pada Mahasiswa Cumlaude dan Non-cumlaude}

Uji korelasi dilakukan untuk menguji hipotesis 3 dan 4. Pada uji ini data yang dibutuhkan berupa data regulasi diri, motivasi belajar, dan prestasi. Data prestasi mahasiswa dibuktikan dengan nilai IP pada semester genap yakni tahun ajaran 2020/2021. Pada uji korelasi ini dilakukan dua kali pengujian yakni untuk menguji adanya: a) korelasi antara regulasi diri, motivasi, dan prestasi belajar mahasiswa cumlaude dan b) korelasi antara regulasi diri, motivasi, dan prestasi belajar mahasiswa noncumlaude. Uji normalitas dilakukan untuk mengetahui kondisi masing-masing variabel berdistribusi normal atau tidak. Berdasarkan Tabel 4 dapat dilihat bahwa nilai sig untuk setiap variabel yaitu sig $>0,05$ yang berarti bahwa seluruh data tersebut berdistribusi normal.

Tabel 4. Uji Normalitas Kelompok Cumlaude

\begin{tabular}{l|cc}
\hline \multirow{2}{*}{ Variabel } & \multicolumn{2}{|c}{ Kolmogorov-Smirnov $^{\mathrm{a}}$} \\
\cline { 2 - 3 } & $\mathrm{N}$ & Sig. (2-tailed) $^{2}$ \\
\hline Regulasi diri & 206 & .200 \\
\hline Motivasi belajar & 206 & .200 \\
\hline IP & 206 & .233 \\
\hline
\end{tabular}

Berdasarkan uji prasyarat yang telah dilakukan maka data penelitian tersebut memenuhi persyaratan untuk dianalisis menggunakan uji korelasi Pearson. Berdasarkan Tabel 5 dapat dilihat bahwa nilai Sig. (2-tailed) $<0.05$, maka terdapat korelasi antar variabel yang dihubungkan. Selain itu, apabila dilihat berdasarkan tanda bintang (**) pada nilai pearson correlation maka antara variabel yang dianalisis terjadi korelasi. Oleh karena itu, berdasarkan hasil uji korelasi tersebut dapat dinyatakan bahwa hipotesis 3 (Ho) ditolak karena terapat korelasi antara regulasi diri, motivasi belajar, dan prestasi pada mahasiswa cumlaude. 
Tabel 5. Hasil Uji Korelasi Regulasi Diri, Motivasi, dan Prestasi Mahasiswa Cumlaude

\begin{tabular}{|ll|r|r|r|}
\hline & & Motivasi & Regulasi & \multicolumn{1}{|c|}{ IP } \\
\hline Motivasi & Pearson Correlation & 1 & $.943^{* *}$ & $.923^{* *}$ \\
& Sig. (2-tailed) & & .000 & .000 \\
Regulasi & $\mathrm{N}$ & 206 & 206 & 206 \\
& Pearson Correlation & $.943^{\star *}$ & 1 & $.875^{\star *}$ \\
& Sig. (2-tailed) & .000 & .000 \\
IP & $\mathrm{N}$ & 206 & 206 & 206 \\
& Pearson Correlation & $.923^{\star *}$ & $.875^{\star *}$ & 1 \\
& Sig. (2-tailed) & .000 & .000 & \\
& $\mathrm{~N}$ & 206 & 206 & 206 \\
\hline
\end{tabular}

${ }^{* *}$. Correlation is significant at the 0.01 level (2-tailed).

Analisis yang sama juga dilakukan untuk menguji hipotesis keempat. Hasil uji normalitas pada kelompok non-cumlaude dapat dilihat pada Tabel 6 . Berdasarkan pada Tabel 6 dapat dinyatakan bahwa seluruh data berdistribusi normal dan layak untuk dilakukan uji korelasi.

Tabel 6. Uji Normalitas Kelompok Noncumlaude

\begin{tabular}{l|cc}
\hline \multirow{2}{*}{ Variabel } & \multicolumn{2}{|c}{ Kolmogorov-Smirnov $^{\mathrm{a}}$} \\
\cline { 2 - 3 } & $\mathrm{N}$ & Sig. (2-tailed) \\
\hline Regulasi diri & 155 & .520 \\
\hline Motivasi belajar & 155 & .600 \\
\hline IP & 155 & .497 \\
\hline
\end{tabular}

Tabel 7 menunjukkan hasil uji korelasi antara regulasi diri, motivasi belajar, dan prestasi mahasiswa non-cumlaude. Berdasarkan hasil tersebut dapat dilihat bahwa nilai Sig (2-tailed) > 0.05, maka tidak terdapat korelasi antara regulasi diri, motivasi belajar, dan prestasi mahasiswa non-cumlaude. Oleh karena itu, hipotesis 4 dinyatakan tidak terbukti atau Ho diterima. 
Tabel 7. Hasil Uji Korelasi antara Regulasi Diri, Motivasi Belajar, dan Prestasi Mahasiswa Non-cumlaude

\begin{tabular}{|ll|r|r|r|}
\hline & & Motivasi_belajar & Regulasi_belajar & Prestasi \\
\hline Motivasi_belajar & Pearson Correlation & 1 & .013 & .127 \\
& Sig. (2-tailed) & & .876 & .115 \\
& $\mathrm{~N}$ & 155 & 155 & 155 \\
Regulasi_belajar & Pearson Correlation & .013 & 1 & -.038 \\
& Sig. (2-tailed) & .876 & & .636 \\
Prestasi & $\mathrm{N}$ & 155 & 155 & 155 \\
& Pearson Correlation & .127 & -.038 & 1 \\
& Sig. (2-tailed) & .115 & .636 & \\
& $\mathrm{~N}$ & 155 & 155 & 155 \\
\hline
\end{tabular}

Berdasarkan hasil yang diperoleh dari uji korelasi dinyatakan bahwa terdapat korelasi yang positif antara kemampuan regulasi diri, motivasi belajar, dan prestasi belajar pada mahasiswa cumlaude. Sebaliknya, hasil dari uji korelasi pada mahasiswa non-cumlaude ternyata dinyatakan korelasi negatif atau tidak ada korelasi antar variabel. Yu (2021) mengungkapkan bahwa pembelajaran daring dapat membawa kerugian bagi mahasiswa yang tidak memiliki kesiapan belajar, sehingga dapat memberikan pengaruh yang buruk pada prestasi belajarnya. Sejalan dengan hasil penelitian tersebut, beberapa faktor yang dapat mempengaruhi kondisi interpersonal mahasiswa selama pembelajaran daring diantaranya infrastruktur yang kurang memadahi dan dukungan para pengajar (dosen) yang belum siap bertransformasi dengan pembelajaran daring (Giatman et al., 2020). Dengan demikian, mahasiswa dengan respon pemikiran yang lambat akan semakin tidak termotivasi untuk melaksanakan kegiatan pembelajaran, sehingga membuat dirinya tidak bisa memiliki pengaturan diri yang baik.

\section{KESIMPULAN}

Berdasarkan hasil penelitian dapat disimpulkan bahwa: 1) terdapat perbedaan kemampuan regulasi diri pada mahasiswa cumlaude dan non-cumlaude, 2) terdapat perbedaan motivasi belajar pada mahasiswa cumlaude dan noncumlaude, 3) terdapat korelasi regulasi diri, motivasi belajar, dan prestasi pada mahasiswa cumlaude, dan 4) tidak terdapat korelasi regulasi diri, motivasi belajar, dan prestasi pada mahasiswa non-cumlaude.

\section{DAFTAR PUSTAKA}

Asmuni, A. (2020). Problematika pembelajaran daring di masa pandemi covid-19 dan solusi pemecahannya. Jurnal Paedagogy, 7(4), 281-288. https://doi.org/10.33394/jp.v7i4.2941

Baldan Babayigit, B., \& Guven, M. (2020). Self-regulated learning skills of undergraduate students and the role of higher education in promoting selfregulation. Eurasian Journal of Educational Research, 89, 47-70. 
https://doi.org/10.14689/ejer.2020.89.3

Cohen, L., Manion, L., \& Morrison, K. (2018). Research methods in education (8th ed.). Taylor \& Francis Group.

Corbeil, J. R., \& Corbeil, M. E. (2015). E-learning: Past, present, and future. In B. H. Khan \& M. Ally (Eds.), International Handbook of E-learning. Routledge. https://doi.org/10.4324/9781315760933.ch3

Diningrat, S. W. M., Nindya, M. A., \& Salwa. (2020). Emergency online teaching: Early childhood education lecturers' perception of barrier and pedagogical competency. Cakrawala Pendidikan, 39(3), 705-719. https://doi.org/10.21831/cp.v39i3.32304

Dron, J. (2018). Smart learning environments , and not so smart learning environments : a systems view. Smart Learning Environments, 5(25), 1-20. https://doi.org/https://doi.org/10.1186/s40561-018-0075-9

Gaumer Erickson, A. S., \& Noonan, P. M. (2017). The skills that matter: Teaching interpersonal and intrapersonal competencies in any classroom (1st ed.). Corwin.

Giatman, M., Siswati, S., \& Basri, I. Y. (2020). Online learning quality control in the pandemic covid-19 era in Indonesia. Journal of Nonformal Education, 6(2), 168-175.

Harandi, S. R. (2015). Effects of e-learning on students' motivation. ProcediaSocial and Behavioral Sciences, 181(October), 423-430. https://doi.org/10.1016/j.sbspro.2015.04.905

Krejcie, R. V, \& Morgan, D. W. (1970). Determining sample size for research activities. Educational and Psychological Measurement, 30, 607-610. https://doi.org/10.1891/9780826138446.0006

Muslimin, A. I., \& Harintama, F. (2020). Online learning during pandemic: Students' motivation, challenges, and alternatives. Loquen: English Studies Journal, 13(2), 60. https://doi.org/10.32678/loquen.v13i2.3558

Pintrich, R. R., \& DeGroot, E. V. (1990). Motivational and self-regulated learning components of classroom academic performance. Journal of Educational Psychology, 82(1), 33-40. https://doi.org/10.5901/mjss.2015.v6n1p156

Saxena, R., Bhat, V., \& Jhingan, A. (2017). Leapfrogging to student at the core. In Federation of Indian Chambers of Commerce and Industry (Issue November).

Sharif, T., Hossan, C. G., \& McMinn, M. (2014). Motivation and determination of intention to become teacher: A case of B.Ed. students in UAE. International Journal of Business and Management, 9(5). https://doi.org/10.5539/ijbm.v9n5p60

Wandler, J. B., \& Imbriale, W. J. (2017). Promoting undergraduate student selfregulation in online learning environments. Online Learning Journal, 21(2), 1-16. https://doi.org/10.24059/olj.v21i2.881

Widjaja, A. E., \& Chen, J. V. (2017). Online learners' motivation in online learning: The effect of online-participation, social presence and collaboration. In C. 
Muniarti \& R. Sanjaya (Eds.), Learning Technologies in Education: Issues and Trends (Issue December, pp. 72-93). Soegijapranata Catholic Univeristy.

Wong, J., Baars, M., Davis, D., Van Der Zee, T., Houben, G. J., \& Paas, F. (2019).

Supporting self-regulated learning in online learning environments and MOOCs: A systematic review. International Journal of Human-Computer Interaction, $35(4-5)$, 356-373. https://doi.org/10.1080/10447318.2018.1543084

$\mathrm{Yu}, \mathrm{Z}$. (2021). The effects of gender, educational level, and personality on online learning outcomes during the COVID - 19 pandemic. International Journal of Educational Technology in Higher Education, 18(14), 1-17. https://doi.org/10.1186/s41239-021-00252-3 